2 Rawlins MD. Adverse reactions and drugs. Br Med $\mathcal{F} 1981$;282:974-6.

${ }^{3}$ Mahgoub A, Idle JR, Dring LD, Lancaster R, Smith RL. The polymorphic hydroxylation of debrisoquine in man. Lancet 1977;ii:584-6.

4 Eichelbaum M, Spannbrucker N, Steincke B, Dengler HJ. Defective $\mathrm{N}$-oxidation of sparteine in man: A new pharmacogenetic defect. Eur $\mathcal{F}$ Clin Pharmacol 1979;16:183-7.

${ }^{5}$ Alvan G. Individual differences in the disposition of drugs metabolised in the body. Clin Pharmacokinet 1978;3:155-75.

${ }^{6}$ Vesell ES, Page JG. Genetic control of drug levels in man: antipyrine. Science (NY) 1968;161:72-3.

' Fraser HS, Mucklow JC, Bulpitt CJ, Kahn C, Mould G, Dollery CT. Environmental factors affecting antipyrine metabolism in London factory and office workers. Br F Clin Pharmacol 1979;7:237-43.

${ }^{8}$ Branch RA, Salih SY, Homeida M. Racial differences in drug metabolizing ability: A study with antipyrine in the Sudan. Clin Pharmacol Ther $1978 ; 24: 283-6$.

${ }^{9}$ Nagy M. Caffeine content of beverage and chocolate. $7 A M A 1974 ; 229: 337$.

${ }^{10}$ Fraser HS, Mucklow JC, Murray S, Davies DS. Assessment of antipyrine kinetics by measurement in saliva. Br $\mathcal{F}$ Clin Pharmacol 1976;3:321-5.

${ }^{11}$ Vestal RE, Norris AH, Tobin JD, Cohen BH, Shock NW, Andres R. Antipyrine metabolism in man: influences of age, alcohol, caffeine and smoking. Clin Pharmacol Ther 1975;18:425-32.

12. Stevenson IH. Factors influencing antipyrine elimination. $\mathrm{Br} f \mathrm{Clin}$ Pharmacol 1977;4:261-5.

${ }^{13}$ O'Malley K, Crooks J, Duke E, Stevenson IH. Effect of age and sex on human drug metabolism. Br Med f 1971 ;iii :607-9.
1 Papita SS. Isoenzyme variation in Northumberland. In: Roberts DF, Sunderland E, eds. Genetic variation in Britain. London: Taylor and Francis, 1973

${ }^{15}$ Hart P, Farrell GC, Cooksley WGE, Powell LW. Enhanced drug metabolism in cigarette smokers. Br Med F 1976;ii:147-9.

16 O'Malley K, Crooks J, Stevenson IH. Impairment of drug metabolism by oral contraceptive steroids. Clin Pharmacol Ther 1972;13:552-7.

17 Roberts DF. Assortative mating in man. Bulletin of the Eugenics Society 1977 ;suppl No 2.

${ }^{18}$ Whittaker JA, Evans DAP. Genetic control of phenylbutazone metabolism in man. Br Med f 1970;iv:323-8.

${ }^{19}$ Kappas A, Anderson KE, Conney AH, Alvares AP. Influence of dietary protein and carbohydrate on antipyrine and theophylline metabolism in man. Clin Pharmacol Ther 1976;20:643-53.

"Pantuck EJ, Pantuck CB, Garland WA, et al. Stimulatory effect of brussel sprouts and cabbage on human drug metabolism. Clin Pharmacol Ther $1979 ; 25: 88-95$.

21 Kolmodin B, Azarnoff DL, Sjoqvist F. Effect of environmental factors on drug metabolism: decreased plasma half-life of antipyrine in workers exposed to chlorinated hydrocarbon insecticides. Clin Pharmacol Ther 1969;10:638-42.

$\because$ Alvares AP, Fishbein A, Anderson KE, Kappas A. Alterations in drug metabolism in workers exposed to polychlorinated biphenyls. Clin Pharmacol Ther 1977;22:140-6.

Accepted 30 September 1981)

\title{
Serum retinol and the inverse relationship between serum cholesterol and cancer
}

\author{
J D KARK, A H SMITH, C G HAMES
}

\begin{abstract}
Several human studies have shown an inverse relation between vitamin $A$ intake (and serum concentrations of retinol and carotene) and cancer. Serum cholesterol concentrations have also been reported in inverse relation to cancer. In a study of 3102 people in Evans County, Georgia, who were followed for over 12-14 years to assess the incidence of cancer there was an inverse association between the risk of cancer and both serum retinol and serum cholesterol concentrations. The data also showed an unexpectedly strong correlation between serum retinol and total cholesterol concentrations.

The inverse relationship with cancer was stronger with serum retinol than with cholesterol, which suggested that the association with cholesterol might be secondary. This suggestion may also explain the cholesterol-cancer association reported in several other cohort studies. Further studies of the relation between serum concentrations of cholesterol, retinol, and carotene and the incidence of cancer are needed.
\end{abstract}

Department of Social Medicine, School of Public Health and Community Medicine, Hebrew University, Hadassah Faculty of Medicine, Ein Karem, Jerusalem, Israel

J D KARK, MD, PHD, epidemiologist

Department of Community Health and Epidemiology Unit, Wellington Clinical School of Medicine, Wellington Hospital, Wellington, New Zealand

A H SMITH, MB, PHD, senior lecturer

Cardiovascular Epidemiology Study, Evans County Heart Research, Claxton, Georgia 30417, USA

C G HAMES, MD, director

\section{Introduction}

A large and rapidly expanding body of laboratory evidence shows that retinoids possess striking antineoplastic properties, inhibiting both the transformation and promotional stages of the neoplastic process. ${ }^{1-3}$ The epidemiological data have recently been reviewed by Peto et al. ${ }^{4}$ Two prospective ${ }^{56}$ and several retrospective dietary studies ${ }^{7-9}$ have shown an inverse relationship between vitamin A intake (mainly in the form of carotene) and cancer. Users of vitamin A pills showed a non-significant reduction in the risk of developing cancer. ${ }^{10} \mathrm{Within}$ wide bounds, blood retinol concentrations are generally little affected by varying vitamin $\mathrm{A}$ intake, ${ }^{4}$ and excessive intake causes a relatively small increase in serum retinol concentrations. ${ }^{11}$ Casecontrol studies of the relationship between serum retinol and serum carotene concentrations and cancer have consistently shown that serum retinol concentrations are lower in patients with cancer than in controls ${ }^{12-20}$ and serum carotene concentrations have also been lower in those studies in which they have been measured. ${ }^{12-1418}$ The question whether low serum values precede the development of cancer or are a consequence of it remains open in these studies. Two prospective studies, however, one in Evans County, Georgia, ${ }^{21} 22$ and the second in England, ${ }^{23}$ have shown an inverse relationship between the risk of cancer and serum retinol concentrations.

Quite separately interest has grown in the inverse relationship between serum cholesterol concentrations and the incidence of cancer. Several studies have reported an inverse relationship between serum or plasma cholesterol concentrations and cancer outcomes, usually mortality. ${ }^{24-28}$ The findings were more apparent for men than women in the three studies that included both sexes. ${ }^{25} 2628$ An Oslo cohort ${ }^{29}$ and the three Chicago study cohorts, ${ }^{30}$ however, did not show an association between cholesterol concentrations and cancer. The major methodological issue in these studies is whether the cancer produces the reduced cholesterol concentration. Rose and Shipley ${ }^{31}$ pre- 
sented data which support this explanation since removal of deaths from the first two years of follow-up eliminated an initial inverse relationship. Data from the Paris prospective study suggest that low serum cholesterol values are a consequence rather than a precurser of cancer. ${ }^{32}$ Analysis by subdividing periods of follow-up, however, or by excluding deaths occurring during the first years does not eliminate the relationship in other studies. ${ }^{25} 2628$

We have previously presented results from the Evans County cardiovascular disease cohort showing that both serum retinol and cholesterol concentrations relate inversely to the incidence of cancer. ${ }^{22}{ }^{25}$ In this paper we tie these results together and show that associations between cholesterol and cancer may be secondary to an association between retinol and cancer.

\section{Methods}

The Evans County cardiovascular disease cohort, a total community study, has been described in detail elsewhere. In 1960-2, 3102 pcople were examined, their serum cholesterol concentrations were measured by the Abell-Kendall method, ${ }^{33}$ and specimens were stored at $-18 \mathrm{C}$ for later examination. New cases of cancer were ascertained up to 1974. Only those cases documented at least 12 months after intake were included. ${ }^{25}$ Retinol concentrations were measured in 1976 on the stored sera of 85 subjects with cancer and 174 controls drawn from the cohort; we used a modified fluorimetric method after alumina column separation. ${ }^{22}$ The question of measuring retinol in old stored sera and the fact that many of the patients' sera had been used for another study whereas many of the control sera had not have been discussed elsewhere. ${ }^{2-2}$ Stability studies performed to simulate the exposure of the sera stored for 14-16 years showed retinol to be stable in ambient laboratory lighting conditions, during exposure at room temperature, and during recurrent freezing and thawing cycles. ${ }^{21}$

\section{Results}

Table I shows age-adjusted differences between the subjects who developed cancer and the controls. The 85 patients had serum

TABLE I-Mean difference in serum cholesterol and serum retinol concentrations between subjects with cancer and controls* selected from the Evans County cohort, adjusted by race-sex-specific regressions on age

\begin{tabular}{|c|c|c|c|c|c|c|}
\hline \multirow[b]{2}{*}{ Subjects } & \multirow[b]{2}{*}{$\begin{array}{l}\text { No of } \\
\text { subjects } \\
\text { with } \\
\text { cancer }\end{array}$} & \multirow[b]{2}{*}{$\begin{array}{l}\text { No of } \\
\text { controls }\end{array}$} & \multicolumn{2}{|c|}{ Serum cholesterol } & \multicolumn{2}{|c|}{ Serum retinol } \\
\hline & & & $\begin{array}{c}\text { Case- } \\
\text { control } \\
\text { difference } \\
(\mathrm{mmol} / \mathrm{l})\end{array}$ & $\begin{array}{c}\text { p value } \\
2 \text {-tailed }\end{array}$ & $\begin{array}{c}\text { Case- } \\
\text { control } \\
\text { difference } \\
(\mu \mathrm{mol} / 1)\end{array}$ & $\begin{array}{l}\text { p value } \\
2 \text {-tailed }\end{array}$ \\
\hline Total & 85 & 174 & -0.28 & 0.05 & -0.23 & 0.002 \\
\hline White men & 31 & 61 & -0.46 & 0.09 & $-0 \cdot 24$ & 0.02 \\
\hline White women & 32 & 70 & $-0 \cdot 16$ & 0.48 & -0.18 & $0 \cdot 16$ \\
\hline Black men & 16 & 29 & -0.23 & (1) 46 & -0.39 & 0.08 \\
\hline Black women & 6 & 14 & -0.04 & 0.92 & -0.08 & $0 \cdot 70$ \\
\hline
\end{tabular}

*Two controls were selected for each of the 92 patients for whom serum was available. Retinol could not be estimated in seven patients and 10 controls because of insufficient serum. Therefore 85 cases and 174 controls remained for analysis Retinol: $1 \mathrm{kmol} 1=28.7 \mu \mathrm{g} 100 \mathrm{ml}$.

cholesterol values $0.28 \mathrm{mmol} / 1(10.8 \mathrm{mg} / 100 \mathrm{ml})$ lower on average than those of the controls $(p-0.05)$, a difference amounting to $5 \%$ of the average study value of $5.6 \mathrm{mmol} / 1(218 \mathrm{mg} / 100 \mathrm{ml})$. For serum retinol the overall difference was $0.23 \mu \mathrm{mol} / 1(6.6 \mu \mathrm{g} / 100 \mathrm{ml} ; \mathrm{p}=0.002)$, a difference amounting to nearly $15 \%$ of the average study value of $1.6 \mathrm{mmol} / 1(46 \mu \mathrm{g} / 100 \mathrm{ml})$. In each race-sex group the difference between patients and controls was proportionately larger and more significant for serum retinol than for cholesterol concentrations, while the differences for both retinol and cholesterol concentrations were larger for men than for women.

The association of serum concentrations of cholesterol and retinol with cancer was remarkably similar when examined by site of the cancer (table II). All 127 cases of cancer analysed in the Evans County cohort were used to examine the relationship between cholesterol concentration and the site of the cancer, while 85 of the 127 cases (for
TABLE II-Mean serum cholesterol* and mean serum retinol $\dagger$ differences between patients grouped according to site of cancer and controls, adjusted by race-sex specific regressions on age

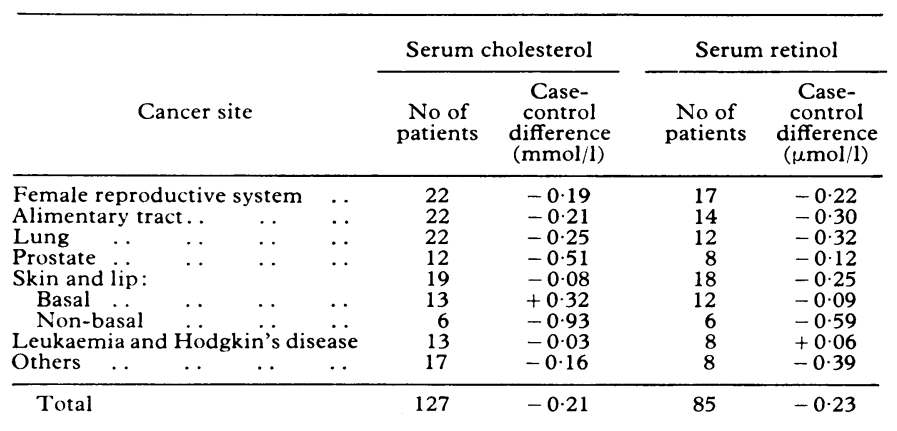

*Adapted from reference 25. †Adapted from reference 22 . *Adapted from reference 25. tAdapted from reference 22 .
Conversion: SI to traditional units-Cholesterol: $1 \mathrm{mmol} / 1 \approx 38.6 \mathrm{mg} / 100 \mathrm{ml}$.
Retinol: $1 \mu \mathrm{mol} / 1 \approx 28.7 \mu \mathrm{g} / 100 \mathrm{ml}$.

whom sera were available) were used for serum retinol comparisons. For those sites showing a reduced concentration of cholesterol, retinol concentrations were proportionately lower (except for cancer of the prostate). In the leukaemia-Hodgkin's disease group, neither cholesterol nor retinol concentrations were lower than expected, while both cholesterol and retinol concentrations showed the same pattern among the patients with skin cancer, with the non-basal cell types (epithelial and melanoma) being associated with lower concentrations than the basal cell cancers.

We are unaware of prior studies on the relationship of serum retinol and serum cholesterol concentrations in healthy adults. In our study (of 92 white men, average age $57.5 ; 102$ white women, average age $54 \cdot 9 ; 45$ black men, average age $62 \cdot 1$; and 20 black women, average age 55.4 ) there was a surprisingly strong association between the two variables (table III), the correlation being stronger and more consistent in whites than in blacks, and evident in both subjects with cancer and controls when analysed separately. Indeed, retinol appeared to be one of the variables most strongly correlated with serum cholesterol concentrations in Evans County.

Because of these statistical associations between serum cholesterol and retinol concentrations, the differences between the subjects with cancer and the controls were assessed for each factor while we controlled for the potential confounding effect of the other (table IV). The association of cholesterol with cancer was much reduced when we controlled for retinol, but the reverse was not apparent. In other words the inverse association between retinol concentrations and the incidence of cancer was mostly independent of cholesterol concentrations, while that of cholesterol concentrations and cancer was strongly related to the retinol-cancer association.

TABLE III-Correlation of serum cholesterol and serum retinol concentrations in the four race-sex groups in Evans County for cases and controls separately ( $p$ values are given in parentheses)

\begin{tabular}{|c|c|c|c|c|}
\hline & White men & White women & Black men & Black women \\
\hline $\begin{array}{l}\text { No of cases } \\
\text { Pearson correlation } \\
\text { No of controls } \\
\text { Pearson correlation }\end{array}$ & 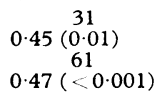 & 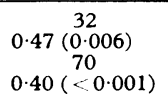 & $\begin{array}{c}16 \\
0.55(0.03) \\
29 \\
0.11(>0.25)\end{array}$ & $\begin{array}{c}-0.17\left(\begin{array}{l}6 \\
14 \\
0.25)\end{array}\right. \\
0.43(0.13)\end{array}$ \\
\hline $\begin{array}{l}\text { Cases and controls } \\
\text { combined } \\
\text { Pearson correlation } \\
\text { Age-adjusted partia }\end{array}$ & $0.48\left(\frac{92}{<0.001)}\right)$ & $0 \cdot 44\left(4^{102}(<0 \cdot 001)\right.$ & $\begin{array}{c}45 \\
0.27 \stackrel{(0.07)}{ }\end{array}$ & $0.26(>0.25)$ \\
\hline correlation & $0.48(<0.001)$ & $0.32(<0.002)$ & $0.26(0.08)$ & $-0.13(>0.25)$ \\
\hline
\end{tabular}

\section{Discussion}

There appear to be three main competing hypotheses to explain the inverse association between cholesterol concentrations and the incidence of cancer. Firstly, lower cholesterol values, even before the manifestation or detection of cancer, may be a result of the cancer process; secondly, lower cholesterol values may precede the development of cancer but the association with cancer is secondary-that is, cholesterol serves as a marker for some other causal variable or set of variables; thirdly, lower cholesterol values may precede the development of cancer 
TABLE IV-Differences in serum cholesterol concentrations between patients and controls with and without controlling for retinol*, and differences in serum retinol concentrations between patients and controls with and without controlling for cholesterol $\dagger$ (two-tailed p values are given in parentheses)

\begin{tabular}{|c|c|c|c|c|c|c|}
\hline & & Total & White men & White women & Black men & Black women \\
\hline $\begin{array}{l}\text { Cholesterol difference }(\mathrm{mmol} / 1) \text { without controlling for retinol } \\
\text { Cholesterol difference }(\mathrm{mmol} / 1) \text { controlling for retinol } \\
\text { Retinol difference }(\mu \mathrm{mol} / \mathrm{l}) \text { without controlling for cholesterol } \\
\text { Retinol difference }(\mu \mathrm{mol} / \mathrm{l}) \text { controlling for cholesterol } \ldots\end{array}$ & $\begin{array}{l}\cdots \\
\cdots \\
\cdots\end{array}$ & $\begin{array}{l}-0.28(0.05) \\
-0.11(0.38) \\
-0.23(0.002) \\
-0.18(0.01)\end{array}$ & $\begin{array}{l}-0.46(0.09) \\
-0.19(0.40) \\
-0.24(0.02) \\
-0.15(0.14)\end{array}$ & $\begin{array}{l}-0.16(0.48) \\
-0.07(0.76) \\
-0.18(0.16) \\
-0.15(0.24)\end{array}$ & $\begin{array}{l}-0.23(0.46) \\
-0.09(0.76) \\
-0.39(0.08) \\
-0.35(0.12)\end{array}$ & $\begin{array}{l}-0.04(0.92) \\
-0.04(0.92) \\
-0.08(0.70) \\
-0.08(0.70)\end{array}$ \\
\hline
\end{tabular}

*By race-sex specific regressions of serum cholesterol on age, age-squared and serum retinol.

$\dagger$ By race-sex specific regressions of serum retinol on age and serum cholesterol.

Conversion: SI to traditional units-Cholesterol: $1 \mathrm{mmol} / 1 \approx 38.6 \mathrm{mg} / 100 \mathrm{ml}$. Retinol: $1 \mu \mathrm{mol} / 1 \approx 28.7 \mu \mathrm{g} / 100 \mathrm{ml}$.

and may be causally associated with the occurrence of some forms of cancer.

The data from Evans County described here suggest that the relationship between cholesterol concentrations and cancer may be secondary to an association between retinol concentrations and the incidence of cancer. Indeed, the lack of a consistent association between cholesterol concentrations and cancer in different studies would lead one to search for a secondary association. Additionally, the evidence that retinol has a protective effect is stronger than the evidence that cholesterol has a protective effect.

The possibility that these findings are due to an artefact resulting from the use of old stored sera that may have been differentially exposed to ambient laboratory conditions cannot be dismissed. Nevertheless, the simulation studies we conducted reduce the probability of such an explanation. The correlation between serum cholesterol and serum retinol concentrations, measured 14-16 years apart, cannot be attributed to such an artefact as the relationship was equally strong in both subjects with cancer and controls. In addition, Wald et $a l,{ }^{23}$ applying a study design almost identical to ours, showed an inverse association between retinol concentrations and the incidence of cancer independent of serum cholesterol values.

The relatively strong correlation between serum retinol and total cholesterol concentrations that we found has recently been confirmed by one of us (AHS) in a New Zealand study, ${ }^{34}$ in which the association was shown to be with low-density lipoprotein cholesterol. This study used serum specimens frozen for several months only and used a different method of estimating serum retinol concentrations. The study also provided preliminary evidence for an association between $\beta$-carotene and cholesterol concentrations, although $\beta$-carotene and retinol concentrations were not associated. Basu et al ${ }^{15}$ also showed a linear relationship between retinol and cholesterol concentrations in a small series of hospital patients with and without cancer. We surmise that the correlation of retinol and cholesterol concentrations reflects a relationship between their carrier proteins-retinol binding protein and low-density lipoproteinand that the determinants of the blood concentrations of these carrier proteins are partly shared.

We suggest that a study of serum cholesterol, serum retinol, and serum carotene concentrations in relation to the incidence of cancer may elucidate the cholesterol-cancer relationships described in published reports. Certainly, further detailed examination of the interrelationship of serum cholesterol, retinol, and carotene concentrations, preferably on fresh specimens, would be of great interest in itself.

\section{References}

${ }^{1}$ Sporn MB, Dunlop NM, Newton DL, Smith JM. Prevention of chemical carcinogenesis by vitamin $\mathrm{A}$ and its synthetic analogues (retinoids). Federation Proc 1976;35:1322-38.

2 Sporn MB, Newton DL. Chemoprevention of cancer with retinoids. Federation Proc 1979;38:2528-34.

3 Boutwell RK. Selected abstracts on vitamin $A$ in cancer biology. International Cancer Research Data Bank (ICRDB). Bethesda, Maryland: National Cancer Institute, 1979.

4 Peto R, Doll R, Buckley JD, Sporn MB. Can dietary beta-carotene materially reduce human cancer rates? Nature $1981 ; 290: 201-7$

5 Bjelke E. Dietary vitamin A and human lung cancer. Int $\mathcal{f}$ Cancer $1975 ; 15$ : 32-44.
${ }_{7}^{6}$ Hirayama T. Diet and cancer. Nutrition and Cancer 1979;1:67-81

${ }^{7}$ Mettlin C, Graham S, Swenson M. Vitamin A and lung cancer. $\mathcal{F}$ Nat Cancer Inst $1979 ; 62: 1435-8$.

${ }^{8}$ Mettlin C, Graham S. Dietary risk factors in human bladder cancer. Am $\mathcal{F}$ Epidemiol 1979;110:255-63.

9 McLennan R, Da Costa J, Day NE, Law CH, Ng YK, Shanmugaratnam K. Risk factors for lung cancer in Singapore Chinese, a population with high female incidence rates. Int f Cancer 1977;20:854-60.

${ }^{10}$ Smith PG, Jick H. Cancer among users of preparations containing vitamin A: a case-control investigation. Cancer 1978;42:808-11.

11 Vahlquist A, Michaelsson G, Juhlin L. Acne treatment with oral zinc and vitamin A: effects on the serum levels of zinc and retinol binding protein (RBP). Acta Derm Venereol 1978;48:437-42.

12 Abels JC, Gorham AT, Pack GT, Rhoads CP. Metabolic studies in patients with cancer of the gastrointestinal tract. 1. Plasma vitamin A levels in patients with malignant neoplastic disease, particularly of the gastrointestinal tract. 7 Clin Invest 1941 ;20:749-64.

13 Wahi PN, Kehar U, Lahiri B. Factors influencing oral and oropharyngeal cancers in India. Br $\mathcal{F}$ Cancer 1965;19:642-60.

${ }^{14}$ Clifford P. Carcinogens in the nose and throat: nasopharyngeal carcinoma in Kenya. Proc Roy Soc Med 1972;65:682-6.

15 Basu TK, Raven RW, Dickerson JW, Williams DC. Vitamin A nutrition and its relationship with plasma cholesterol level in the patients with cancer. Inter $\mathcal{F}$ Vit Nutr Res $1974 ; 44: 14-8$.

${ }^{16}$ Basu TK, Donaldson D, Jenner M, Williams DC, Sakula A. Plasma vitamin $A$ in patients with bronchial carcinoma. Br $\mathcal{F}$ Cancer $1976 ; 33$ : 119-21.

${ }^{17}$ Cohen MH, Primack A, Broder LE, Williams LR. Vitamin A serum levels and dietary vitamin $\mathrm{A}$ intake in lung cancer patients. Cancer Letters $1977 ; 4: 51-4$.

${ }^{18}$ Ibrahim J, Jafarey NA, Zuberi SJ. Plasma vitamin A and carotene levels in squamous cell carcinoma of oral cavity and oropharynx. Clinical Oncology $1977 ; 3: 203-7$.

19 Capel ID, Williams DC. The relationship between zinc and vitamin A in cancer patients. IRCS Medical Science 1979;7:361-71.

${ }^{20}$ Atukorala S, Basu TK, Dickerson JWT, Donaldson D, Sakula A. Vitamin A, zinc and lung cancer. Br f Cancer 1979;40:927-31.

${ }^{21} \mathrm{Kark}$ JD. The relationship of serum vitamin $A$ and serum cholesterol to the incidence of cancer in Evans County, Georgia. Doctoral dissertation, University of North Carolina, Chapel Hill, NC, 1977.

${ }^{22}$ Kark JD, Smith AH, Switzer BR, Hames CG. Serum vitamin A (retinol) and cancer incidence in Evans County, Georgia. F Natl Cancer Inst $1981 ; 66: 7-16$.

${ }^{23}$ Wald $N$, Idle $M$, Boreham J, Bailey A. Low serum vitamin A and subsequent risk of cancer. Lancet 1980;ii:813-5.

${ }^{24}$ Rose G, Blackburn H, Keys A, Taylor HL, Kannel WB, Paul O, Reid DD, Stamler J. Colon cancer and blood cholesterol. Lancet 1974 ; : 181-3.

${ }^{25}$ Kark JD, Smith AH, Hames CG. The relationship of serum cholesterol to the incidence of cancer in Evans County, Georgia. 7 Chron Dis 1980; 33:311-22.

${ }^{26}$ Beaglehole R, Foulkes MA, Prior IAM, Eyles EF. Cholesterol and mortality in New Zealand Maoris. Br Med F 1980;280:285-7.

${ }^{27}$ From the NIH. Cholesterol and noncardiovascular mortality. $\mathcal{F} A M A$ $1980 ; 244: 25$.

28 Williams RR, Sorlie PD, Feinleib M, McNamara PM, Kannel WB, Dawber TR. Cancer incidence by levels of cholesterol. FAMA 1981; $245: 247-52$.

29 Westlund $\mathrm{K}$, Nicolaysen $\mathrm{R}$. Ten year mortality and morbidity related to serum cholesterol. Scand $\mathcal{7}$ Clin Lab Invest 1972;30, Suppl 127:1-24.

30 Dyer AR, Stamler J, Paul O, Shekelle RB, Schoenberger JA, Berkson DM, Lepper M, Collette P, Shekelle S, Lindberg HA. Serum cholesterol and risk of death from cancer and other causes in three Chicago epidemiological studies. Cited in Preventive Medicine 1979;8:688.

${ }^{31}$ Rose G, Shipley MJ. Plasma lipids and mortality: a source of error. Lancet $1980 ; \mathrm{i}: 523-6$.

32 Cambien F, Ducimetiere P, Richard J. Total serum cholesterol and cancer mortality in a middle-aged male population. Am f Epidemiol 1980;112: 388-94.

${ }^{33}$ McDonough JR, Hames CG, Stulb SC, Garrison GE. Cardiovascular disease field study in Evans County, Georgia. Characteristics of the study population. Pub Health Report 1963;78:1051-9.

${ }^{34}$ Smith AH, Hoggard BM. Retinol, carotene, and the cancer/cholesterol association. Lancet 1981;i:1371-2.

(Accepted 8 September 1981) 